\title{
THE DYSTOPIAN FORMULA IN MARGARET ATWOOD'S \\ NOVEL THE HANDMAID'S TALE: INTERLACEMENT OF TRADITIONS AND NOVATION
}

\section{Olena Kotsiuba ${ }^{1}$}

DOI: https://doi.org/10.30525/978-9934-26-050-6-57

With the birth of humanism in Renaissance society mankind has obtained many significant discoveries, one of which is utopia (firstly described by Thomas More in the A little, true book, not less beneficial than enjoyable, about how things should be in a state and about the new island Utopia, 1516). The idealized image of existence in the last century is replaced by anti-utopia (or dystopia) - the story about the «future without a future», a dead mechanized society, where man is assigned the role of a simple social unit. Presently, it is one of the most relevant and widespread genres of world literature, which is constantly replenished with new original samples (Suzanne Collins, Stephen King, John Christopher, Margaret Atwood, Veronica Roth, Lauren DeStefano, etc.). No wonder, that nowadays there are already a lot of researches where scholars view current issues of dystopian literature. Priority

\footnotetext{
${ }^{1}$ Kryvyi Rih State Pedagogical University, Ukraine
} 
in them is given to such considerable items as the definition, origin, genre specificity, etc.

In modern literary studies, however, there are many issues, focusing on various genre characteristics of anti-utopia, namely, versatile changes of the dystopian model in modern works, new approaches to the correlation between utopia and anti-utopia. For example, I. Samorukov formulates the following definition of this concept: «Anti-utopia, dystopia, negative utopia are images (usually in fiction) of dangerous, destructive and unpredictable consequences associated with creating a society that corresponds to a certain social ideal» [3]. Besides defining, the scholar here pays special attention to the fact that the genre of anti-utopia represents not only a negatively coloured description of a potentially possible future, but it disputes with utopia - an image of a society claiming perfection, but with the so-called value-negative paradigm.

It is necessary to remark that scholars' interest to anti-utopia has in much increased since the second half of the XX th century. Here one can't help mentioning the problem of «formality», which was firstly viewed by John G. Cawelti in his book Adventure, Mystery, and Romance: Formula Stories as Art and Popular Culture (1976). The author distinguishes two types of formulae: cultural stereotypes and plot formulae. The formula can be called any culturally determined stereotype: «stupid Americans», «brunette bitches», eccentric detectives with remarkable analytical skills. But J. Gawelti points out that these are traditional constructs that are conditioned by a particular culture of a particular time, which beyond of this specific context may have a different meaning: «Such common plot schemes are story lines (fables) that are popular if not everywhere, but at least in many cultures for a long time. In fact, they can be seen as an example of what some researchers call archetypes, or patterns» [1].

Formula literature is consequently characterized by sticking to the certain models (patterns), which gives the writer the opportunity to quickly and efficiently create popular texts and simultaneously brings the reader a sense of comfort and predictability. Novelty is approved only if it reinforces the expected emotions and does not change them radically. Due to Gawelti's assumption, each of the formula genres is built according to certain laws, uses standard plot moves, operates with well-known symbols and archetypes, as well as cultural stereotypes of the society in which a particular piece of fiction is created. To J. Gawelti's mind, therefore, anti-utopia may be identified as formula genre.

Having analyzed several XX century iconic novels of the of this genre (We by E. Zamyatin, Brave New World by A. Huxley, 1984 and Animal Farm by G. Orwell and others), S. Yarovaya managed to draw up a scheme of a «classical» anti-utopia [4]. Thus, taking into account the scholars' conclusions 
about anti-utopia as the genre that is arranged due to some formulae and may obtain some scheme of fictional organization, one can assume that these features can be found in modern anti-utopian prose.

In particular, a deep analytical reading of $\mathrm{M}$. Atwood's novels enabled to make certain conclusions about formality signs in her The Handmaid's Tale (1985). By the way, this modern Canadian writer is widely popular among both world readers and scholars, and its popularity is caused by different reasons. For example, E. Zharkova in inclined to assert that the term «middle literature» is helpful to understand the specificity of this work, as «the intellectualization of mass literature and simplification of elite literature are inextricably linked» [6]. She is convinced that the enormous popularity of this novel among recipients is explained by this fact, not for the last turn.

For scholars, indeed, The Handmaid's Tale is a fiction where they can research the traditional anti-utopian features, as well as M. Atwood's new approaches towards writing. It is a novel where the woman-author not only made use of classical rules, but also resorted to the transformation of the genre pattern of dystopia. So, the goal of this article is to represent the traditional and the new in her structuring a fictional anti-utopian world.

The following features of the anti-utopian pattern are thought to be traditional as they were inherited by M. Atwood from her great predecessors' novels.

1. The state of Gilead is depicted as quite prosperous, with wellestablished economic and industrial spheres. The level of development determines its significance and impact in a global context.

2. The problem of the influence of a political regime or technical revolution on the individual and society is relevant (for example, depersonalization, i.e. quasi-nomination, restrictions in language and movement, choice of clothing, etc.).

3. The main conflict in M. Atwood's anti-utopian novel is the tragic relationship between the individual and the system - the author focuses on the main character, suffering from being numerously accused by the totalitarian regime.

4. The typical features of this genre are also a prominent protagonist and a clearly constructed plot based on the disagreement of this character with the rules of the current regime.

5. Like in all classical anti-utopias, in Handmaid's Tale the states described choose a totalitarian way of impact on citizens. Gilead is an example of a theocratic state with an established dictatorial regime.

6 . The government in this novel is headed by a narrow group of military elites who helped establish the regime (the so-called Commanders). 
7. The fundamental details of this genre can be called the obligatory presence of the love line, the existence of rituals in the characters' lives, a particular spatial and temporal organization of the anti-utopian world.

8. The action of the novel takes place in a narrow space - the state of Gilead, which is protected from the outer world by a wall, where the corpses of executed «criminals» are regularly hung, most of whom are convicted of political reasons.

9. The plot of Atwood's novel is formally divided into halves by the internal rebellion of the protagonist, and the external development of the action (war, revolution, catastrophe, which were the impetus for the establishment of a pseudo-utopian state). In the The Handmaid's Tale the main events take place due to the coup.

In addition to them, however, M. Atwood initiated to involve women images into a dystopian fictional world. The key characters of her novel are women, around them the development of the plot unfolds (Offred, Serena Joy, Ofglen, Aunt Lydia). That is why, apparently, Atwood's novel is a new word in the development of the genre of modern dystopia, which Yu. Zhadanov calls «feministic dystopia.» This scholar adds that the woman-author vividly demonstrates what social consequences a constant indulgence in men's whims and dreams about the «true» purpose of women (home, family, children) can lead to [5]. One should also keep in mind that Atwood does not simply describe events on behalf of women, she actively uses women's consciousness to reflect special aspects of the suppression of the individual "self». For example, women's rights in this world: women are fired from their jobs, being said that «you can't work here anymore, this is the law» [2]; their financial accounts are blocked, the funds from which are transferred to the closest male relative. Another bright example is freedom of choice for women, which is realized by depicting various restrictions. Also, through the eyes of Offred, the author demonstrates the women's attitude towards marriage and family responsibilities, using the example of the relationship between the Commanders and their wives, as well as representing the heroine's reminiscences about her past life with her husband.

So, we are eligible to conclude that The Handmaid's Tale by Margaret Atwood can be regarded as a typical and, at the same time, original example of a dystopian piece of prose, which is characterised by traditions and novation interlacement in arranging a fictional world.

\section{References:}

1. Cawelti J. G. (1976) Adventure, Mystery, and Romance: Formula Stories as Art and Popular Culture. Chicago: University of Chicago Press, 344 p. 
2. Etvud M. (2019) Rasskaz Sluzhanki [The Handmaid's Tale]. Moskva: EKSMO. (in Russian)

3. Samorukov I. I. (2006) Massovaya literatura: problema khudozhestvennoy refleksii [Mass literature: the problem of artistic reflection] (PhD Thesis), Samara: Samarskiy gosudarstvennyy universitet.

4. Yarovaya S. S. (2017) Formula ideal'noy antiutopii [The formula for the perfect dystopia]. Moskovskiy gorodskoy konkurs issledovatel'skikh i proektnykh rabot uchashchikhsya [Moscow City Competition of Research and Design Works of Students] (electronic journal). Retrieved from: http://mgk.olimpiada.ru/media/ work/4495/Для_конкурса.docx (accessed 06 March 2021).

5. Zhadanov Yu. A. (2013) Osobennosti sovremennoy angloyazychnoy antiutopii [Features of modern English-speaking dystopia]. Svitova literatura na perekhresti kuljtur $i$ cyvilizacij [World literature at the crossroads of cultures and civilizations] (electronic journal), vol. 7, no. 2, pp. 71-84. Retrieved from: https://cyberleninka.ru/ article/n/18350196 (accessed 06 March 2021).

6. Zharkova E. P. (2017) Antiutopii M. Etvud «Rasskaz Sluzhanki» i «Trilogiya Bezzumnogo Addama» v kontekste traditsii i noveyshikh tendentsiy v razvitii zhanra [M. Atwood's dystopias «The Handmaid's Tale» and «Mad Addam's Trilogy» in the context of tradition and the latest trends in the development of the genre] (PhD Thesis), Voronezh: Voronezhskiy gosudarstvennyy universitet. 